\title{
Human Rights Protection: The Role of Institutional Capacity and Selective Adaptation
}

\author{
Pitman B. Potter \\ Institute of Asian Research and Peter A. Allard \\ School of Law \\ University of British Columbia
}

\section{APDR Working Paper Series Volume 1 Number 1}

\section{ISSN 2371-6304}

(c) $($ )(9) $\Theta$

This article is made available as part of the Asia Pacific Dispute Resolution

Working Paper Series and is licensed under a Creative Commons Attribution-NonCommercial-NoDerivatives 4.0 International License 


\title{
HUMAN RIGHTS PROTECTION: THE ROLE OF INSTITUTIONAL CAPACITY AND SELECTIVE ADAPTATION*
}

\author{
Pitman B. Potter \\ Institute of Asian Research and Peter A. Allard School of Law \\ University of British Columbia
}

We have examined previously the role of institutional capacity and selective adaptation in the interaction between international rule regimes on trade and human rights and local norms and practices, in the context of globalization. ${ }^{1}$ This work is ongoing, through archival and survey research on the relationship between acceptance of globalized rule regimes among interpretive communities charged with interpreting, applying, and enforcing non-local rules, and the resilience of local norms. This paper will examine the potential application of selective adaptation and institutional capacity to understanding of international human rights norms and practices.

\section{Protection of Human Rights: Issues of Institutional Capacity}

Enforcement of international human rights norms depends on the capacity of intermediary institutions. Institutional capacity refers to the ability of institutions to perform their assigned tasks. Institutional capacity has been examined from relational perspectives that focus on issues of responsibility between organizations and their constituencies; efficiency in performance and the use of resources; and accountability to varying sources of authority. ${ }^{2}$ Functional perspectives have also been applied to the question of institutional capacity, in such areas as access to information; effectiveness and methods of

\footnotetext{
* This paper was prepared as a working paper in 2005 for a conference at Mofid University in Qom, Iran. I did not attend the conference due to human rights abuses in Iran. This working paper has not been published or updated, although parts have been updated and included in subsequent publications.

${ }^{1}$ Pitman B. Potter, "Legal Reform in China: Institutions, Culture, and Selective Adaptation” (2004) 29:2 Law \& Social Inquiry 465 at 465-95.

${ }^{2}$ H.V. Savitch, "Global Challenge and Institutional Capacity: Or How We Can Refit Local Administration for the Next Century" (1998) 30:3 Administration \& Society 248 at 248-73.
} 
communication; organizational symmetry; and ability to enforce rules and directives. ${ }^{3}$ However useful these approaches may be in the abstract, actual institutional performance remains contingent on domestic political and socio-economic conditions. ${ }^{4}$ In many economies, local conditions of rapid socio-economic and political transformation pose particular challenges for institutional capacity. Accordingly, institutional capacity in China may usefully be examined by reference to issues of institutional location, orientation, cohesion, and most importantly institutional purpose.

Institutional capacity also depends on issues of Geographical Location, particularly the question of balancing central authority with decentralization of social and economic development initiatives. ${ }^{5}$ Many societies exhibit tension between local and central authorities and among the regions. The practical divisions of power and authority between local and central government departments permit an interplay of power and politics between the central and sub-national governments that echoes practices of federalism. Yet this may conflict with state-directed ideals of conformity and unity. In the process of bargaining that accompanies the allocation of resources and the distribution of costs and benefits of policy initiative, requirements of submission to the unified state may limit the flexibility of local officials. Rigid adherence to contested ideals of unitary authority also may limit the ability of legal institutions at both local and national levels to exercise even limited autonomy in support of predictability and stability in socio-economic and political relations. As a result institutional capacity of the legal system more broadly suffers. In the human rights context, this may affect the ability of local institutions to carry out central government edicts purporting to protect human rights.

Institutional capacity also depends on Institutional Orientation. Orientation refers to the priorities and habitual practices that inform institutional performance. For human rights

\footnotetext{
${ }^{3}$ William Blomquist and Elinor Ostrom, "Institutional Capacity and the Resolution of a Commons Dilemma" in Michael D. McGinnis, ed., Polycentric Governance and Development: Readings from the Workshop in Political Theory and Policy Analysis (Ann Arbor: University of Michigan Press, 1999).

${ }^{4}$ P. Healey, "Building Institutional Capacity through Collaborative Approaches to Urban Planning" (1998) 30:9 Environment \& Planning 1531 at 1531-46; Lisa L. Martin and Beth A. Simmons, "Theories and Empirical Studies of International Institutions" (1998) 52:4 Int'1 Org 729 at 729-57.

5 James S. Wunsch, "Institutional Analysis and Decentralization: Developing an Analytical Model for Effective Third World Administrative Reform” in McGinnis, supra note 3.
} 
institutions, orientation involves particularly the tension between formal and informal modes of operation. Much has been written on the role of informal networks as vehicles for socio-economic regulation and development. Informal networks may serve as a substitute for the norms and processes associated with formal institutions, allowing more flexible responses to increasingly complex social, economic and political relations. However, the potential role of informal institutions is often challenged by development policies of political regime which insist on maintaining formal organizational systems to defend ideological orthodoxy and enforce political loyalty. The tension between statist ethics of formal institutionalism and local informal arrangements may work to divert resources from institutional performance and undermines institutional capacity. In the human rights context, this may undermine the ability of governments to deliver the opportunities for development that the right to development requires as well as the civil and political rights envisioned under the Universal Declaration of Human Rights.

Finally, institutional capacity depends on issues of Institutional Coherence, involving the willingness of individuals within institutions to comply with edicts from organizational and extra-organizational leaders, and enforce institutional goals. Compliance concerns the recognition and enforcement of norms. ${ }^{6}$ Conflicts arise when the norms of particular organizations differ from those of the individuals within these organizations - such as where norms of public policy that drive organizational priorities require subordination of parochial interests of individual officials within the organization. Often the lack of institutional coherence is revealed through the presence of corruption. This has an effect not only on the emergence of human rights abuses, which often are the result of challenges to arbitrary and abusive exercise of authority, and their resolution, which may require punishment of officials protected by extensive patronage networks.

Of the elements of institutional capacity that affect enforcement of human rights norms, perhaps the most important is Institutional Purpose. Institutional purpose concerns the way in which the goals of institutions reflect material and ideological contexts, the availability

\footnotetext{
${ }^{6}$ Amitai Etzioni, ed., A Sociological Reader on Complex Organizations, 2d. ed. (New York: Holt, Rinehart and Winston, 1969); Amitai Etzioni, A Comparative Analysis of Complex Organizations (New York: Free Press, 1961).
} 
and nature of financial, human and other resources, and the various limitations that attend institutional performance. Institutional purpose plays a significant role in determining the capacity of institutions to respond to socio-economic change. Political and legal institutions often function according to the policy priorities imposed upon them by the local regimes. The "relative autonomy" ascribed to legal institutions in the European and North American traditions is often limited in developing economies outside the European tradition. Thus, the capacity of legal institutions reflects the extent of commonality of purpose between legal norms and processes and the policy imperatives of the local government. This involves a dynamic of selective adaptation.

\section{Selective Adaptation: An Overview}

As discussed previously, the notion of "selective adaptation" proceeds from assumptions about the importance of cultural norms in influencing behavior. Cultural norms are reflected in rules, including formal laws and regulations and informal procedures and practices. The distinction between rules and the cultural norms they represent becomes especially important when rules particular to one cultural group are used by another, without a corresponding assimilation of underlying norms. This phenomenon is reflected in current conditions of globalization, as liberal rules of governance generally associated with the Europe and North America are disseminated to other areas, but little attention is given to questions about local acceptance of the norms on which these rules are based.

Selective adaptation describes a process by which practices and norms are exchanged across cultural boundaries. Selective adaptation is made possible by ways in which governments and elites express their own normative preferences in the course of interpretation and application of practice rules. Selective adaptation also operates within societies as different groups interact with and respond to dominant discourses. While selective adaptation explains much about the general conditions for exchange of practices, rules, and norms between cultural communities, more work is needed to confirm the operational details of selective adaptation, identify the internal components, and explain the implications for cross-cultural dispute resolution. 
Selective adaptation depends on a number of factors, including perception, complementarity, and legitimacy. Perception influences understanding about foreign and local norms and practices. Perceptions about the purpose, content and effect of foreign and local trade law norms and practices affect the processes and results of selective adaptation. For example, local government efforts to comply with international trade rules on transparency while still pursuing local policy priorities may hinge on the content and accuracy of perceptions about treaty norms and practices and their relationship to local systems. The interpretation and application of non-local rules in light of local norms thus depends on perceptions about both. Drawing on principles of nuclear physics, complementarity describes a circumstance by which apparently contradictory phenomena can be combined in ways that preserve essential characteristics of each component and yet allow for them to operate together in a mutually reinforcing and effective manner. ${ }^{7}$ Complementarity may allow adjustment of norms and practices of particular cultural communities to satisfy expectations imposed from outside, while still protecting local needs. For example, local compliance with international trade rules on state subsidies may depend on complementarity in procedure, as the formality of imported practice rules is reconciled with the flexibility of local performance standards. Thus, complementarity affects the potential for non-local rules and local norms to be mutually sustaining. Legitimacy concerns the extent to which members of local communities support the purposes and consequences of selective adaptation. ${ }^{8}$ Whereas the forms and requirements of legitimacy may vary, the effectiveness of selectively adapted dispute resolution norms and practices depends to an important degree on local acceptance. For example, if local economic actors challenge efforts to regulate production costs according to international anti-dumping rules, this will affect the possibilities for selective adaptation. Other factors, such as coincidence, socio-economic or political crisis, and voluntary experimentation may also play a role.

\footnotetext{
${ }^{7}$ Niels H. D. Bohr, Essays, 1958-1962, on Atomic Physics and Human Knowledge (New York: Interscience Publishers, 1963); Richard Rhodes, The Making of the Atomic Bomb (New York: Simon and Schuster, 1986) at 13 et seq.

${ }^{8}$ Max Weber, Economy and Society: An Outline of Interpretive Sociology, Guenther Roth and Claus Wittich, eds. (Berkeley and Los Angeles: University of California Press, 1978); Stephen P. Turner and Regis A. Factor, Max Weber: The Lawyer as Social Thinker (London and New York: Routledge, 1994).
} 


\section{Selective Adaptation of Human Rights Norms: The Right to Development in Comparative Context}

The dynamic of selective adaptation is illustrated in the ways that divergent international human rights norms have been accepted by developing economies. In contrast to liberal norms of individual liberties and civil and political rights, many developing economies have emphasized the right to development. The right to development has been the focus of much debate and discussion, particularly in the context of its relationship to other human rights and in light of the economic development achievements and aspirations of states in the East Asian Region. ${ }^{9}$ A comparison of two major human rights documents of 1993the Bangkok Declaration and the Vienna Declaration - reveals significant differences of view concerning the right to development and its place in international human rights law. The Bangkok Declaration suggested that state governments should be free to give development goals priority over other human rights policies, which themselves could be limited by local cultural and historical conditions. ${ }^{10}$ This approach was viewed with some trepidation by outside observers, in part because the Bangkok Declaration also suggested that the recognition and enforcement of human rights generally should be controlled by local governments free from outside scrutiny. ${ }^{11}$ The Vienna Declaration, by contrast, stressed that the lack of development may not be used to justify abridgement of internationally recognized human rights, thus underscoring the principles accepted elsewhere that all human rights (including the right to development) are universal, indivisible, and interrelated. ${ }^{12}$

The contradiction over the relationship of the right to development and its attendant circumstances and other human rights reveals significant philosophical differences concerning the nature of development and the nature of rights. While these contradictions are

\footnotetext{
${ }^{9}$ See Pitman B. Potter, "The Right to Development: Philosophical Differences and Political Implications," in Errol Mendes and Anne-Marie Traeholt, eds., Human Rights: Chinese and Canadian Perspectives (Ottawa: Human Rights Research and Education Centre, 1997).

${ }^{10}$ See "Final Declaration of the Regional Meeting for Asia of the World Conference on Human Rights" (1993) 14 Hum Rts LJ 370, Art. 8 [“Bangkok Declaration"].

11 Ibid, Art. 24 provides that the conceptualization and eventual establishment of national human rights institutions should be left to the States to decide.

${ }^{12}$ See United Nations World Conference on Human Rights, "Vienna Declaration and Programme of Action" (1993) 32 ILM 1661 at 1665-66, Arts. I (5) and I (10). While the Bangkok Declaration repeated some of the standard doctrinal language of human rights law on universality and indivisibility, its emphasis on the prerogatives of state governments and the contextualization of rights marked a significant departure.
} 
unlikely to be resolved in the short term, the approach to development embodied in the Bangkok Declaration may have less than positive political implications for authoritarian development regimes. More importantly, these differing perspectives play a significant role in the formation of institutional purpose as an element of institutional capacity.

\section{A. Summary of the Discourse of the Right to Development}

While it would be superfluous in the extreme to retrace in detail the genealogy of the right to development, a brief summary may be useful as background. It is useful as well to note the institutional context within which these debates take place.

\section{Recognition of the Right to Development as a Human Right}

International recognition of the right to development as a human right has often been traced to a speech by Mr. Justice Keba M'Baye, First President of the Senegal Supreme Court, to the International Institute for Human Rights in $1972 .{ }^{13}$ However, the idea has long-standing roots in the United Nations Charter, the Universal Declaration of Human Rights, the International Covenant on Economic, Social and Cultural Rights, the International Covenant on Civil and Political Rights, and other international instruments. ${ }^{14}$ The politics of North-South relations and particularly the call for a "New International Economic Order" have contributed as well to assertions about the existence of a right to development. ${ }^{15}$ Support for the right to development has been found in scholarly studies, ${ }^{16}$ and gradually a series of international

\footnotetext{
${ }^{13}$ See Keba M'Baye, “Le Droit au developpement commen un droit de l'Homme” (1972) 5 Revue des Droits de l'Homme 503. See also Hector Gros Espiell, "The Right to Development as a Human Right" (1981) 16:2 Texas Int'1 LJ 189 at 192; Russel Lawrence Barsh, “The Right to Development as a Human Right: Results of the Global Consultation" (1991) 13:3 Hum Rts Q 322.

${ }^{14}$ See e.g., Roland Y. Rich, “The Right to Development as an Emerging Human Right” (1983) 23:2 Va J Int'l L 287; Ved P. Nanda, “The Right to Development: An Appraisal“" in Ved P. Nanda, George W. Shepherd, Jr., and Eileen McCarthy-Arnolds, eds., World Debt and the Human Condition: Structural Adjustments and the Right to Development (New York: Greenwood Press, 1992) at 41-61.

${ }^{15}$ For a useful collection of articles presented at a 1991 seminar convened in Calcutta by the Committee on Legal Aspects of the New International Economic Order of the International Law Association, see Subrata Roy Chowdhury, Erik M.G. Denters, \& Paul J.I.M. de Waart, eds., The Right to Development in International Law (Dordrecht: Martinus Nijhoff, 1992). Also see Mohammed Bedjaoui, "Some Unorthodox Reflections on the 'Right to Development"' in Francis Snyder \& Peter Slinn, ed., International Law of Development: Comparative Perspectives (Abingdon: Professional Books, 1987) at 87-116.

${ }^{16}$ Among the earliest and most articulate proponents of the right to development have been Roland Rich and Philip Alston. See e.g. Rich, "The Right to Development as an Emerging Human Right" supra note 14 and Roland Rich, "The Right to Development: A Right of Peoples?” in James Crawford, ed., The Rights of Peoples (Oxford: Clarendon, 1988) at 39-54; Philip Alston, "Development and the Rule of Law: Prevention versus Cure as a Human Rights Strategy“ in International Commission of Jurists, Development, Human Rights and the Rule
} 
instruments has emerged recognizing and expanding on the right to development. ${ }^{17}$ Ideas about the right to development have undergone further revision in the context of the dynamic growth of economies in the East Asian region, and amid suggestions that these economic successes vindicate an "Asian" cultural approach to development that stands as an alternative to much of Western human rights thinking. ${ }^{18}$

But there have been dissenting voices. Some suggest that the right to development is little more than an attempt by authoritarian governments to insulate their regimes from outside scrutiny. ${ }^{19}$ Sceptical observers also suggest that the right to development has little if any legal support and is in effect an attempt to enshrine the laudable goal of development as a right, rather than recognizing that development may be the end-product of the enforcement of various civil, political, economic, social and/or cultural rights, but is not (and should not be) a right in itself. ${ }^{20}$ Other critics have suggested that the emerging doctrine of the right to development gives undue attention to economic growth, which not only entrenches a flawed view of development generally, but also works to further the subjugation of disadvantaged groups for whom the right to development ought to operate most strongly. ${ }^{21}$

A middle ground of sorts is occupied by observers who accept the notion of a right to development, but who insist that it operate only as a complement and not a substitute for other

of Law (1981) [Alston, "Development and the Rule of Law"]; Philip Alston, "Making Space for New Human Rights: The Case of the Right to Development" (1988) 1 Hum Rts Yrbk 3 [Alston, "Making Space"]; Philip Alston, "Revitalizing United Nations Work on Human Rights and Development" (1991) 18 Melbourne Univ L Rev 216 [Alston, "Revitalizing UN Work"]. For a critical review of Alston, see Jack Donnelly, "In Search of the Unicorn: The Jurisprudence and Politics of the Right to Development" (1985) 15:3 Cal W Int'l LJ 473.

${ }^{17}$ Of particular importance have been the UNESCO Secretary General's Report on the Right to Development (E/CN.4/1334) (1979); the United Nations General Assembly's Declaration on the Right to Development (Res 41/128) (1986); and the UNESCO Commission on Human Rights' Report on the Global Consultation on the Right to Development as a Human Right (E/CN.4/1990/9/Rev.1) (1990).

${ }^{18}$ Perhaps the most comprehensive articulation of the right to development in the context of the East Asian experience was the 1993 Bangkok Declaration, in which the emphasis was placed on local historical, cultural and religious conditions as context for human rights conditions. See Bangkok Declaration, supra note 10. Also see Susumu Awanohara, Michael Vatikiotis, and Shada Islam, "Vienna Showdown" (June 17, 1993) Far Eastern Economic Review at 16.

${ }^{19}$ See Michael Vatikiotis and Robert Delfs, "Cultural Divide: East Asia Claims the Right to Make Its Own Rules" (June 17, 1993) Far Eastern Economic Review at 20.

${ }^{20}$ See e.g. Donnelly, supra note 16. Cf. John O’Manique, "Human Rights and Development" (1992) 14:1 Hum Rts Q 78; John O’Manique, “Development, Human Rights and Law” (1992) 14:3 Hum Rts Q 383.

${ }^{21}$ See e.g., Hilary Charlesworth, "The Public/Private Distinction and the Right to Development in International Law" (1992) 12 Austl YB Int'l L 190; Jonathan L. Mannina, "The Human Rights Implications of Economic Development: A Case Study of the Huaorani People of Ecuador” (1992) 5:1 Geo Int'l Envtl L Rev 91. 
human rights. ${ }^{22}$ The interaction of development with other human rights has been seen to require that the local peoples affected by economic development projects have meaningful opportunities for participation and consultation. ${ }^{23}$ The right to participation has been expanded yet further in an effort to suggest that it might be a basis for protection of cultural rights against oppression from authoritarian states. ${ }^{24}$

\section{Institutional Contexts}

Debates over the right to development operate against a background of political structures that affect and often pre-determine the content of the debate. Of particular importance are the views of national governments, international aid agencies, nongovernmental organizations, and the scholarly community. Although there are of course significant interdependencies among these institutions, their identity, power, and goals each play a significant role in determining the content of views expressed by their representative interlocutors.

As international law is the creation of states, it is not surprising that state governments have played a critical role in discussions of the right to development. Governments in developing states have been particularly eager to have a right to development recognized at the international level, and for institutional mechanisms for enforcement to be put in place. Thus, for example, the UNESCO Secretary General's Report on the right to development

\footnotetext{
${ }^{22}$ The text of the 1994 Vienna Declaration stands as a forceful articulation of this view, "[w]hile development facilitates the enjoyment of all human rights, the lack of development may not be invoked to justify the abridgement of internationally recognized human rights". See United National World Conference on Human Rights, "Vienna Declaration and Programme of Action" (1993) 32 ILM 1661 at 1666, Art. I (10). For scholarly expressions of this perspective, see e.g., Rhoda E. Howard, "Law and Economic Rights in Commonwealth Africa" (1985) 15:3 Cal W Int'l LJ 607; Kivutha Kibwana, "Human Rights And/Or Economic Development: Which Way Africa?" [1993] Third World Leg Studies 43; Wade Mansell and Joanne Scott, "Why Bother About a Right to Development?" (1994) 21:2 JL \& Soc 171; Yemi Osinbajo and Olukonyisola Ajayi, "Human Rights and Economic Development" (1994) 28:3 Int'l Lawyer 727.

${ }^{23}$ See e.g., Konrad Ginther, "Participation and Accountability: Two Aspects of the Internal and International Dimension of the Right to Development" [1992] Third World Leg Studies 55; James C.N. Paul, "Law and Development into the '90s: Using International Law to Impose Accountability to People on International Development Actors" [1992] Third World Leg Studies 1 [Paul, "Into the '90s"]; James C.N. Paul, "The Human Right to Development: Its Meaning and Importance" (1992) 25:2 John Marshall L Rev 235; Daniel D. Bradlow, "Human Rights, Public Finance and the Development Process: A Critical Introduction" (1992) 8:1 Am Univ J Int'l L \& Pol'y 1.

${ }^{24}$ See e.g., Michele L. Radin, "The Right to Development as a Mechanism for Group Autonomy: Protection of Tibetan Cultural Rights" (1993) 68:3 Wash L Rev 695.
} 
emphasized the moral duty of industrialized states to repair the economic disparities that characterize their relations with developing countries, an NIEO theme that has been taken up repeatedly in subsequent instruments on the right to development. ${ }^{25}$ Obviously, such an approach to international rights and duties suits the economic interests of developing states, particularly where implementation mechanisms and policies are established. On the other hand, international instruments on the right to development also reflect the views of industrialized states in noting the importance of domestic development efforts. ${ }^{26}$

Much of the discussion over the right to development has concerned efforts by international aid agencies to explain and justify their activities. As with most formal institutions, international aid agencies have organizational interests and a parochial commitment to continuing their work and maintaining control over it. ${ }^{27}$ Thus, aid agencies have been quick to respond to human rights criticisms of their work. Employees of aid agencies, while careful to note that they speak in their personal capacity, more often than not reflect the views of their employers. Thus, in response to claims that international aid should be tied to the human rights records of recipient counties, the General Counsel of the World Bank has argued that the Bank's charter mandates an effort to promote economic development and the raising of living standards, without direct attention to political questions. ${ }^{28}$ As well, the point is made that the right to development gives the Bank's activities a direct human rights element. In response to claims that they play insufficient attention to local participation, international aid agencies

\footnotetext{
${ }^{25}$ See UNESCO Secretary General, Report on the Right to Development, supra note 17 at 20; United Nations General Assembly, Declaration on the Right to Development (Res 41/128) (1986), Preamble; UNESCO Commission on Human Rights, Report on the Global Consultation on the Right to Development as a Human Right (E/CN.4/1990/9/Rev.1) (1990), Art. V (F) [UNESCO Commission on Human Rights, Report on the Global Consultation].

${ }^{26}$ See United Nations General Assembly, Declaration on the Right to Development, supra note 25; UNESCO Commission, Report on the Global Consultation, supra note 25 at Art. V (A).

${ }^{27}$ See generally, Robert A. Packenham, Liberal America and the Third World: Political Development Ideas in Foreign Aid and Social Science (Princeton: Princeton University Press, 1973).

${ }^{28}$ See Ibrahim F.I. Shihata, "The World Bank and Human Rights: An Analysis of the Legal Issues and the Record of Achievements" (1988) 17:1 Den J Int'l L \& Pol'y 39; Ibrahim F.I. Shihata, "Human Rights, Development, and International Financial Institutions" (1992) 8:1 Am Univ J of Int'l L \& Pol'y 27. Also see Mr. Shihata's comments on a panel entitled "Environment, Economic Development and Human Rights: A Triangular Relationship?" in Proceedings of the Eighty-Second Annual Meeting of the American Society of International Law (1988) at 41-45.
} 
often resort to examples of linkages with local elite organizations without much reflection as to whether these linkages contribute to meaningful local participation.

The role of NGOs in the debates over the right to development has become increasingly important. ${ }^{29}$ While they often are subject to repression from local governments-either through direct repression or through the establishment of government organized competitors (GO-NGOs), ${ }^{30}$ - non-government organizations have often embarked on courageous efforts to articulate views on development matters that stand in contrast to those of state governments and international development agencies. ${ }^{31}$ And while they are often accused of being dominated by local elites rather than broadly participatory, NGOs have shown a capacity for expanding the discourse of the right to development beyond the confines often imposed by state governments.

While academic scholars are usually employed by universities, their loyalties are often to schools of thought rather than to the organizations with which they are associated. These loyalties play a significant role in setting the parameters for academic discussion. Thus, for example, scholars who criticize the right to development adopt liberal paradigms which focus on the individual as the primary beneficiary of political rights. ${ }^{32}$ Other critics have challenged the right to development through allegiance to and application of the principles of feminist theory. ${ }^{33}$ By contrast, those who have argued in support of the right to development have done so by reference to ideas about the importance of collective rights as at least equal to (and often

\footnotetext{
${ }^{29}$ See Sidney Jones, “The Organic Growth: Asian NGOs Have Come into Their Own” (June 17, 1993) Far Eastern Economic Review at 23. For discussion of the potential role of NGOs in human rights monitoring, see Ann Kent, "China and the International Human Rights Regime: A Case Study of Multilateral Monitoring, 19891994” (1995) 17:1 Hum Rts Q 1.

${ }^{30}$ See Geoffrey Crothall, "Outlawed Dissent: The Stranglehold on Unofficial Groups" (Winter 1993) China Rights Forum at 8-9; Sharon Hom, "Listening for Diversity" (Winter 1993) China Rights Forum at 12-15.

${ }^{31}$ For discussion of the role of NGOs at the Bangkok Conference, see Sidney Jones, "Culture Clash: Asian Activists Counter Their Governments' Restrictive View of Human Rights" (Summer 1993) China Rights Forum at $8-9,22$. See also "Mangu fei zhengfu zuzhi xuanyan (zhaiyao)" (Bangkok NGO communique: Excerpts) (Summer 1993) China Rights Forum at 35-36.

${ }^{32}$ See Jack Donnelly, "In Search of the Unicorn: The Jurisprudence and Politics of the Right to Development", supra note 16.

${ }^{33}$ See e.g., Charlesworth, supra note 21; Marilyn Waring, "Gender and International Law: Women and the Right to Development" (1988-89) 12 Austl YB Int'l L 177.
} 
with priority over) individual rights. ${ }^{34}$ In each of these lines of argument, the views expressed owe as much to the authors' underlying conceptual paradigms as they do to their immediate research and analysis. Thus, along with the political perspectives of national governments and the institutional perspectives of aid agencies and their employees, the views of academics on the right to development reveal structural determinants which are not less real for their basis in ideas rather than organizations.

\section{B. The Nature of Development and the Nature of Rights}

Discussion about the right to development reflects different ideas about the nature of development and the nature of rights. An examination of these underlying paradigms is useful in understanding the broader debates about the right to development.

\section{Dimensions of Development}

Among the many points of conflict in approaches to development are the questions about the international dimensions of development and underdevelopment; the goals of development; and the implications of development for social, economic and political relations.

\section{a. International Dimensions of Development: The Issue of Dependency}

Between supporters and opponents of the right to development, the basic issues revolve around issues of international political economy. Proponents of the right to development are heavily influenced by the conclusions of dependency theory. ${ }^{35}$ Critics on the other hand suggest that dependency theory explains very little, and that local conditions offer more powerful explanations for development and under-development.

The cadre of scholars broadly labelled dependency theorists, hold in general that underdevelopment in all its forms is due in large part to the exploitation and oppression by the industrialized West-first through colonialism and later through domination of the

\footnotetext{
${ }^{34}$ See e.g. Rich, "The Right to Development as an Emerging Human Right" supra note 14 and Rich, "The Right to Development: A Right of Peoples?", supra note 16; Alston, "Development and the Rule of Law", supra note 16; Alston, "Making Space", supra note 16; Alston, "Revitalizing UN Work", supra note 16.

${ }^{35}$ For example, the Human Rights White Paper issued by the People's Republic of China in 1991 makes much of the century of colonial oppression suffered by China during the 19th and early 20th centuries. See "Text of Human Rights White Paper" (November 21, 1991) FBIS Daily Report - Supplement.
} 
international finance, technology, and commodity systems. ${ }^{36}$ Early proponents of dependency portrayed local elites rather crudely as corporatist allies of foreign capital, serving as conduits for investment and also as the primary local beneficiaries. ${ }^{37}$ Their commercial and consumption activities are seen to support the objectives of foreign investment, by substituting short-term parochial goals for priorities of building the technological and infrastructural foundations for long-term development. ${ }^{38}$

Critics have suggested that proponents of dependency theory have indulged in holistic ideological viewpoints that are not amenable to falsification or testing, even to the point of descending into what one observer has called a "fusion of scholarship, politics, and theatre." 39 Rather than explain conditions and causes of underdevelopment, dependency theorists are accused of overlooking local political and policy causes for underdevelopment. ${ }^{40}$ Pointing to the successes of the East Asian newly-industrialized countries (NICs), critics of dependency theory have suggested that local conditions can overcome the effects of external oppression, even to the point of rendering it irrelevant to the question of development. ${ }^{41}$

\footnotetext{
${ }^{36}$ There is a rich and wide-ranging literature on the problems of dependency. Among the most useful works are Paul A. Baran, The Political Economy of Growth (New York: Monthly Review Press, 1968); Andre Gunder Frank, Capitalism and Underdevelopment in Latin America: Historical Studies of Chile and Brazil (New York: Monthly Review Press, 1967); Celso Furtado, Development and Underdevelopment: A Structural View of the Problems of Developed and Underdeveloped Countries (Berkeley: University of California Press, 1964); Johan Galtung, "An Economic Theory of Imperialism" (1971) 8:2 J Peace Research 81 at 81-117; Alejandro Portes, "On the Sociology of National Development: Theories and Issues" (1976) 82:1 Am J Sociology 55 at 55-85; Immanuel Wallerstein, "The Rise and Future Demise of the World Capitalist System: Concepts for Comparative Analysis" (1974) 16:4 Comp Studies Soc'y \& History 1 at 1-26; and Charles K. Wilber, ed., The Political Economy of Development and Underdevelopment, 2d ed. (New York: Random House, 1979). For a not uncritical survey of the dependency literature, see Robert A. Packenham, The Dependency Movement: Scholarship and Politics in Development Studies (Cambridge, Mass.: Harvard University Press, 1992) [Packenham, The Dependency Movement].

${ }^{37}$ See generally, Fernando Henrique Cardoso and Enzo Faletto, Dependency and Development in Latin America, trans. Marjory Mattingly Urquidi (Berkeley: University of California Press, 1979); Paul Baran, "On the Political Economy of Backwardness" in Wilber, supra note 36 at 91-113. See also Charles K. Wilber and James H. Weaver, "Patterns of Dependency: Income Distribution and the History of Underdevelopment" in Wilber, supra note 36 at 114-129. For a critique, see Packenham, The Dependency Movement, supra note 36 at 93-94.

${ }^{38}$ See generally, Marshall R. Singer, Weak States in a World of Power: The Dynamics of International Relationships (New York: Free Press, 1972); Ronald Muller, "The Multinational Corporation and the Underdevelopment of the Third World" in Wilber, supra note 36 at 151-78.

${ }^{39}$ See Packenham, The Dependency Movement, supra note 36, esp. at 315.

${ }^{40}$ See Stephan Haggard, Pathways From the Periphery: The Politics of Growth in the Newly Industrialized Countries (Ithaca, NY: Cornell University Press, 1990) at 19-22.

${ }^{41}$ See e.g., Osinbajo \& Ajayi, supra note 22.
} 
While arguments continue to proliferate as to the strengths and weaknesses of dependency theory, it remains influential in the discourses of the right to development and of human rights generally. Indeed, not a few East Asian political leaders have suggested that the human rights agenda of the West is aimed at perpetuating the dependency of the developing world. ${ }^{42}$

\section{b. The Goals of Development}

Among proponents of the right to development, there is substantial disagreement over the goals of development. While most scholars and international instruments agree that development means more than simply economic growth, some national governments have suggested that economic growth is the primary feature of development.

The primary documents articulating a right to development are fairly clear that development entails more than simply economic growth. Thus, the UNESCO Secretary General's Report indicates that development includes both material and non-material elements. ${ }^{43}$ The UN General Assembly Resolution on the Right to Development contains similar provisionsindicating that development is a comprehensive phenomenon entailing economic, social, cultural, and political elements. ${ }^{44}$ These views are supported and reiterated by a substantial body of scholarly literature. In the wake of perceived failures of development policies that gave primacy to economic growth, ${ }^{45}$ the field of development studies has moved steadily toward a multi-dimensional view of development. ${ }^{46}$ This theme appears throughout the

\footnotetext{
${ }^{42}$ See comments of Malaysian Prime Minister Datuk Seri Mahathir Mohammad in Michael Vatikiotis and Robert Delfs, "Cultural Divide: East Asia Claims the Right to Make Its Own Rules" (June 17, 1993) Far Eastern Economic Review at 20.

${ }^{43}$ UNESCO Secretary General, Report on the Right to Development, supra note 17 at 13 . Most recently, see the UNESCO Secretary General's Position Paper delivered to the 1995 Copenhagen Summit, in which the point is made that development is first and foremost social, rather than economic.

${ }^{44}$ See United Nations General Assembly, Declaration on the Right to Development, supra note 25, Preamble and Art. 1.

${ }^{45}$ See e.g., W.W. Rostow, "The Take-Off to Self-Sustained Economic Growth" in W.W. Rostow, ed., Stages of Economic Growth: A Non-Communist Manifesto (Cambridge, UK: Cambridge University Press, 1960).

${ }^{46} \mathrm{~A}$ seminal work in pointing to the failures of uni-dimensional development policies was Robert A. Packenham, Liberal America and the Third World, supra note 27. Other influential early works were Mahbub ul Haq, The Poverty Curtain: Choices for the Third World (New York: Columbia University Press, 1976).
} 
literature on the right to development, which asserts consistently that development means more than simply economic growth. ${ }^{47}$

Despite this apparent uniformity, a number of national governments in the East Asian region suggest that development means primarily if not exclusively economic growth. Thus, the Bangkok Declaration draws an explicit link between development and the international macroeconomic system. ${ }^{48}$ In its various human rights White Papers, the government of the PRC explicitly adopted a position supporting the primacy of economic growth by stressing the right to subsistence as primary right from which all other rights derive. ${ }^{49}$ Similarly, the yearly reports issued by the PRC government on economic and social development give clear priority to economic achievement. ${ }^{50}$ Singaporean representatives have consistently made clear their conclusions about the primacy of economic growth as a precursor to other aspects of development. ${ }^{51}$ These views stand in marked contrast to the conclusions of international instruments and development scholars that development must mean more than economic growth. More importantly, they have implications for the ways in which state governments

\footnotetext{
${ }^{47}$ See e.g, Theo C. van Boven, "The Right to Development and Human Rights" (1982) 28 Int'l Commission Jurists Rev 49; Espiell, supra note 13; Rich, "The Right to Development as an Emerging Human Right", supra note 14; Ved P. Nanda. "The Right to Development Under International Law: Challenges Ahead" (1985) 15:3 Cal W Int'l LJ 431; Rhona E. Howard, "Law and Economic Rights in Commonwealth Africa" (1985) 15 Cal W Int'l LJ 607; Bradlow, supra note 23; Paul, "Into the '90s", supra note 23; Kibwana, supra note 22; Wade Mansell \& Scott, supra note 22; Charlesworth, supra note 21.

${ }^{48}$ See Bangkok Declaration, supra note 10, Preamble and Art. 18.

${ }^{49}$ See "Text of Human Rights White Paper" supra note 35; "The Progress of Human Rights in China," (December 27, 1995) Xinhua Domestic Service, in FBIS Daily Report: China (December 28, 1996) at 8-26; State Council Information Office, "White Paper: Fifty Years of Progress in China's Human Rights" (2000); State Council Information Office, "Progress in China's Human Rights Cause" (2001).

${ }^{50}$ See e.g., "Statistical Communique of the State Statistical Bureau of the People's Republic of China on the 1993 National Economic and Social Development" (February 28, 1994) China Economic News, Supp. No. 3, in which nearly six pages of the seven page report are devoted to economic growth statistics. This pattern was repeated in the 1994 Communique. See "Statistical Communique of the State Statistical Bureau of the People's Republic of China on the 1994 National Economic and Social Development" (March 27, 1995) China Economic News, Supp. No. 1.

${ }^{51}$ Speaking "in his personal capacity", Kishore Mahbubani, a deputy secretary of Singapore's Ministry of Foreign Affairs, suggested that "[e]conomic development is the only force that can liberate the Third World". see Kishore Mahbubani, "Live and Let Live: Allow Asians to Choose Their Own Course" (June 17, 1993) Far Eastern Economic Review at 26. Also see Chong Li Choy, Tan Chwee Huat, Wong Kwei Cheong, and Caroline Yeoh, eds., Business, Society and Development in Singapore (Singapore: Times Academic Press, 1990), which emphasizes economic and business growth as the touchstone of Singapore's development. Similar sentiments are evident in Linda Low and Toh Mun Heng, eds., Public Policies in Singapore: Changes in the 1980s and Future Signposts (Singapore: Times Academic Press, 1992). Also see comments of Chen Heng Chee, Executive Director of the Singapore International Foundation in Hans De Jonge, "Democracy and Economic Development in the Asia-Pacific Region: The Role of Parliamentary Institutions” (1993) 14 Hum Rts LJ 301 (1993).
} 
address the relationship between economic development and other social, cultural and political relationships.

\section{c. Development and Social, Economic and Political Relations}

Tied closely to notions about the goals of development are questions about the relationship of development to social, economic and political relations. Thus, as might be expected, international instruments and scholarly analyses that assert development to mean more than simply economic growth also argue that the pursuit of development cannot operated to the detriment of other human rights. The UNESCO Secretary General's Report asserts that the right to development operates in tandem with other civil, political, social, cultural, and economic rights. ${ }^{52}$ The UN General Assembly Resolution on the Right to Development asserts that as a human right the right to development is indivisible and interdependent on other human rights. ${ }^{53}$ Similarly, the scholarly literature is nearly uniform in its insistence that the right to development cannot be used to justify denial of other human rights. ${ }^{54}$

However, these views are contradicted by policies and behavior of various governments in the East Asian Region. Reflecting their conclusions about the economic bases for development, some states have subordinated the enforcement of human rights norms in social, economic, and political relations to policy goals of economic development. Relying partly on a critique of liberal paradigms that limit state involvement in economic life through to establishment of free market systems supported by private law rules and institutions, ${ }^{55}$ the

\footnotetext{
${ }^{52}$ See UNESCO Secretary General, Report on the Right to Development, supra note 17 at 13.

${ }^{53}$ See United Nations General Assembly, Declaration on the Right to Development, supra note 25, Art. 6.

${ }^{54}$ See sources cited in note 20, supra.

${ }^{55}$ Liberal economic policies are seen to undermine local capacity to control foreign capital, as the transnational character of foreign business inhibits control by local governments through traditional legal mechanisms. See generally, Robert O. Keohane and Ooms Van Doorn, "The Multinational Firm and International Regulation" (1975) 29:1 Int'l Org 186 at 186-206. Also see Yash P. Ghai, Robin Luckham, and Francis G. Snyder, eds., The Political Economy of Law: A Third World Reader (New Delhi: Oxford University Press, 1987); Francisco Orrego Vicun, "The Control of Multinational Enterprises" in George Modelski, ed., Transnational Corporations and World Order: Readings in International Political Economy (San Francisco: W.H. Freeman \& Co., 1979) at 296308; Franklin B. Weinstein, "Underdevelopment and Efforts to Control Multinational Corporations" in Modelski, at 338-46; Ronald Müller, "Poverty is the Product" (Winter 1973-74) 13 Foreign Policy at 71-102; United Nations, Multinational Corporations in World Development (New York: United Nations, 1973); and Stephen Hymer, "The Multinational Corporation and the Law of Uneven Development" in Jadwish N. Bhagwati, ed., Economics and World Order: From the 1970's to the 1990's (New York: MacMillan, 1972) at 113-35. In the international trade context, see David Kennedy, "Turning to Market Democracy: A Tale of Two Architectures" (1991) 32:2 Harv Int'l LJ 373 at 373-96.
} 
right to development has been used to justify continued restriction of effective judicial systems that might lay a foundation for meaningful civil and political rights. ${ }^{56} \mathrm{By}$ asserting that countries have the right to determine their own political systems through which to pursue economic, social, and cultural development, the Bangkok Declaration clearly subordinated the pursuit of civil and political rights. ${ }^{57}$ China's human rights White Papers emphasize suggest that civil and political relations must continually be subordinated to the pursuit of the right to development. ${ }^{58}$ The Director of the State Council Information Office has supported explicitly the primacy of economic conditions as the basis for development: "[W]e enable our people to have the economic foundation upon which they can enjoy political rights." 59

\section{The Nature of Rights}

Debates over the right to development also reflect fundamental differences about the nature of rights. These differences include divergent views on the sources and beneficiaries of rights.

Much of what might be termed the conventional human rights discourse derives from European ideas about the nature of rights. The inalienable character of human rights and the claim that they are enjoyed by virtue of being human is entrenched in the Universal Declaration of Human Rights as well as the International Covenants on Civil and Political and on Economic, Social, and Cultural Rights. These ideas about the inherency of rights reflect European natural law theories about the equality of human beings, ${ }^{60}$ which in turn derived from a range of political and economic interests. ${ }^{61}$ Despite recent efforts to reconceptualize

\footnotetext{
${ }^{56}$ Perhaps the most direct expression of this sentiment has been attributed to Malaysian Prime Minister Mahathir Mohamad: "developing nations cannot always afford luxuries such as human rights . . liberty must take a back seat to the exigency of economic expansion ... you must eat before you vote." See Boo Tion Kwa, "Righteous Talk" (June 17, 1993) Far Eastern Economic Review at 28.

${ }^{57}$ See Bangkok Declaration, supra note 10, Art. 6.

${ }^{58}$ See "Text of Human Rights White Paper" supra note 35.

${ }^{59}$ See "Interview with Zhu Muzhi, Director of the State Council Information Office" (November 2, 1991) Xinhua, in FBIS Daily Report-China (November 4, 1991) 15-16 at 16.

${ }^{60}$ See generally Jeffrie G. Murphy and Jules L. Coleman, Philosophy of Law: An Introduction to Jurisprudence, rev. ed. (Boulder: Westview Press, 1990). Among the primary sources for this view are Aristotle's Ethics and Politics; Cicero's The Republic, and Aquinas' Treatise on Law. Also see generally, Stephen Lukes, Individualism (Oxford: Blackwell, 1973) and Joseph Raz, "Rights and Individualism" in The Morality of Freedom (Oxford: Clarendon Press, 1986).

${ }^{61}$ Michael E. Tigar and Madeline R. Levy, Law and the Rise of Capitalism (New York: Monthly Review Press, 1977) and Harold J. Berman, Law and Revolution: The Formation of the Western Legal Tradition (Cambridge, Mass.: Harvard University Press, 1985).
} 
rights as claims set in a context of diverse social, political and economic interests, ${ }^{62}$ the notion of inherency retains its appeal and distinguishes the European ideal of rights from that which is emerging in the East Asian region. ${ }^{63}$

In contrast to natural rights theories that view rights as inalienable and intrinsic to the human condition, proponents of the so-called "Asian approach" to rights suggest that rights are conferred by social organizations-families, communities, and governments. Under this approach rights are not inherent, but rather are specific benefits conferred and enforced at the discretion of the state. Such an approach permits governments to silence their critics under the guise of legal process.

Divergent views on the sources of rights have led in turn to significant differences concerning the beneficiaries of rights. In keeping with natural law theories that treat rights as inherent to human beings, the European liberal tradition has long held that human individuals are the primary beneficiaries of rights. ${ }^{64}$ Reflecting this tradition, international human rights instruments provide that human rights are enjoyed by individuals, while the bulk of scholarly literature on human rights suggests as well that the primary beneficiary is the individual. ${ }^{65}$ While currently there is a growing body of literature that challenges this view, ${ }^{66}$ or at least suggests that individual rights can be meaningfully enforced only in the context of community, ${ }^{67}$ the primacy of the individual in the dynamic of legal rights and obligations remains a dominant feature of European and North American rights doctrine.

In the course of the human rights discourse, some governments in East Asia for example claim that groups and communities should be the primary beneficiaries of rights, and by implication

\footnotetext{
${ }^{62}$ See generally, Jeremy Waldron, Theories of Rights (Oxford: Oxford University Press, 1984) and J. Raz, "On the Nature of Rights" (1984) 93:370 Mind 194.

${ }^{63}$ See Ronald Dworkin, Taking Rights Seriously (Cambridge, Mass.: Harvard University Press, 1978).

${ }^{64}$ See generally, Lukes, supra note 60; Raz, "Rights and Individualism", supra note 60.

${ }^{65}$ See generally, Hugh M. Kindred, Phillip Martin Saunders, Jutta Brunnée and Robert J. Currie, eds., International Law: Chiefly as Interpreted and Applied in Canada (Toronto: Emond Montgomery, 1993), Ch. 10. ${ }^{66}$ See generally, Bryan Schwartz, "Individuals, Groups and Canadian Statecraft" in Richard F. Devlin, ed., Canadian Perspectives on Legal Theory (Toronto: Emond Montgomery, 1991) at 39-56.

${ }^{67}$ See e.g. Jeremy Waldron, "Can Communal Goods be Human Rights?" (1987) 28:2 Euro J Sociology 296 and Gillian Triggs, "The Rights of Peoples and Individual Rights: Conflict or Harmony?" in James Crawford, The Rights of Peoples (Oxford: Clarendon, 1988) at 141-57.
} 
at least that the rights of individuals should be subordinated. ${ }^{68}$ This approach is supported by arguments about social and historical traditions, and references to an East Asian familial tradition that derives from Confucianism and its assumptions about authority and hierarchy in social organization. ${ }^{69}$ In this regard, it is useful to note that while the tradition of collective rights in the Asian tradition is much discussed, there is also significant evidence to suggest that the role of the individual was once highly prized. ${ }^{70}$ The importance of the individual in traditional Chinese philosophy, for example, came gradually to be suppressed as a result of the political and ideological imperatives of the Chinese state. ${ }^{71}$ Moreover, it should be noted that Confucianism and the collectivist norms it has engendered have been severely criticized by many contemporary Chinese thinkers as overly authoritarian and repressive. ${ }^{72}$ Nonetheless, the Confucian tradition remains important in the views of some governments in East Asia regarding the beneficiaries of rights.

\footnotetext{
${ }^{68}$ For indicators of the Chinese view, see references to the primacy of national political stability and the livelihood of people throughout the country, in "Text of Human Rights White Paper", supra note 35 at 4 and references to human rights conditions of the Chinese people as whole in "Interview with Zhu Muzhi, Director of the State Council Information Office" (November 2, 1991) Xinhua, in FBIS Daily Report-China (November 4, 1991) at 15-16. See e.g. De Jonge, supra note 51. Also see Boo Tion Kwa, supra note 56 at 28.

${ }^{69}$ See generally, Ann Kent, Between Freedom and Subsistence: China and Human Rights (Hong Kong: Oxford University Press, 1993) at 30-32 [Kent, Between Freedom and Subsistence]; David E. Christensen, "Breaking the Deadlock: Toward a Socialist Confucianist Concept of Human Rights in China" (1992) 13:2 Mich J Int'l L 469. The importance of Confucianism as a basis for a collectivist legal order is the focus of many officially sanctioned studies of Chinese legal culture. See e.g., Chinese Society for the Study of Confucianism and Legal Culture, ed., Confucianism and Legal Culture (Shanghai: Fudan University Press, 1992).

${ }^{70}$ See Donald J. Munro, The Concept of Man in Early China (Stanford: Stanford University Press, 1969) at 17: "all people are equally deserving; all should be tolerated, none singled out for favor". While the Taoists did espouse a primitive solidarity within society, this was derived from a fundamental respect for the identity of the individual. See generally, Joseph Needham, Science and Civilization in China, vol. II (Cambridge: Cambridge University Press, 1954) at 99 et seq. and 139 et seq.

${ }^{71}$ For discussion of individualism and its suppression by early Confucian orthodoxy, see Etienne Balazs, Chinese Civilization and Bureaucracy, A.F. Wright, ed., trans. H.M. Wright (New Haven: Yale University Press, 1964) at 21-22, 177. The emergence of activism and reformism in the "new text Confucianism" of the 19th century raised the possibility of increased tolerance for individualistic scholarship and research within the literati elitea significant departure from the staid intellectual collectivism of prior years, although this too was ultimately unsuccessful. See Benjamin A. Elman, From Philosophy to Philology: Intellectual and Social Aspects of Change in Late Imperial China (Cambridge, Mass.: Harvard University Press, 1984) at 26-36 and Benjamin A. Elman, Classicism, Politics, and Kinship: The Ch'ang-chou School of New Text Confucianism in Late Imperial China (Berkeley: University of California Press, 1990), Ch. 9.

${ }^{72}$ See e.g., Bo Yang, The Ugly Chinaman and the Crisis of Chinese Culture, trans. \& ed. Don J. Cohn and Jing Qing (North Sydney, NSW: Allen \& Unwin, 1992); Wang Ruoshui, "Wei rendao zhuyi bianhu" (In defense of humanism) in Wang Ruoshui, ed., Wei rendao zhuyi bianhu (Beijing: United Press, 1986) at 217-33. Also see Kent, Between Freedom and Subsistence, supra note 69 at 136-53.
} 
These basic differences over nature of development and the nature of rights pose significant obstacles to attempts to reconcile differing approaches on the human right to development differences which are entrenched further by the institutional contexts within which the various views are articulated. In this regard, it is of particular interest to note the emphasis placed by the 1993 Bangkok Human Rights Declaration on a "dynamic and evolving process of international norm-setting" as a context for human rights ideals. ${ }^{73}$ This suggests a hope on the part of some East Asian governments that the human right to development as a multi-faceted, inherent and inalienable right might ultimately yield to a different vision, one that holds the right to development as priority that permits economic growth to take precedence over such other human rights as may be conferred by state governments on their subjects.

The affirmation of the human right to development has put fundamental questions about development and rights on the public agenda of international law and politics. The discourse may yield increasingly effective calls for a multi-dimensional approach that validates social, cultural, and political development as essential counterparts to economic growth. And while it remains to be seen whether authoritarian regimes in the East Asian region will come to adopt such an approach in the near term, the liberalization policies of Taiwan and South Korea suggest that political self-preservation may mandate the adoption of comprehensive development strategies. The development aspirations of the people in the region generally would seem to depend on similar transitions from state-controlled unidimensional economic development to a more comprehensive approach. This in turn will depend on how the philosophical differences and political implications of the right to development are resolved.

\section{Conclusion}

Enforcement of international human rights norms depends on the capacity of local political and legal institutions. Institutional capacity depends on issues of location, orientation, and cohesion, but most of all on factors of institutional purpose. Questions about institutional purpose invite discussion of the relationship between the goals of certain international

\footnotetext{
${ }^{73}$ See "Final Declaration of the Regional Meeting for Asia of the World Conference on Human Rights", supra note 10, Art. 8. See also Osinbajo \& Ajayi, supra note 22.
} 
human rights norms and the goals of local political authorities. The right to development offers a vision of human rights that differs markedly from the liberal ideals of individual rights, and offers an example of the ways in which the dynamic of selective adaptation operates to mediate international norms and local enforcement. Selective adaptation might also offer an approach to resolving tensions between conflicting international and local human rights norms, and thereby a bases for mutual understanding and common commitment to recognizing and protecting the rights of all people. 